Article

\title{
Disaster Risk Governance in Indonesia and Myanmar: The Practice of Co-Governance
}

\author{
Annisa Gita Srikandini ${ }^{1, *}$, Roanne Van Voorst ${ }^{2}$ and Dorothea Hilhorst ${ }^{2}$ \\ ${ }^{1}$ Department of International Relations, Gadjah Mada University, 55284 Yogyakarta, Indonesia; \\ E-Mail: annisagita@ugm.ac.id \\ 2 International Institute of Social Studies, Erasmus University Rotterdam, 2518 AX The Hague, The Netherlands; \\ E-Mail: vanvoorst@iss.nl \\ * Corresponding author
}

Submitted: 5 June 2018 | Accepted: 7 September 2018 | Published: 28 September 2018

\begin{abstract}
This article discusses the discourse and practice of co-governance in disaster risk reduction (DRR). It is based on an extensive ethnographic study of DRR at global level and in two disaster-prone countries in Southeast Asia: Indonesia and Myanmar. These country cases were selected not only because of their similarly high vulnerability to disasters, but also because the overlaps and differences between them in disaster governance allowed for a comparative study of the impacts of co-governance in DRR. Indonesia is characterised by a longer history with democratic governance institutions and a largely national-led response to disasters; Myanmar has only started to develop DRR in the last 10 years, and its policies are still largely led by international actors. In both countries, disaster response has shifted from being top-down and statecentred to following a co-governance approach. This reflects a worldwide trend in DRR, the idea being that co-governance, where different state and non-state stakeholders are involved in governance networks, will lead to more inclusive and effective DRR. Our findings suggest that, in Myanmar and Indonesia, DRR has indeed become more inclusive. However, at the same time, we find that DRR in both countries has remained highly hierarchical and state-centred. Although the possible gains of encouraging future initiatives among different actors negotiating disaster response is under-explored, we find that, to date, the multiplication of actors involved in DRR, especially within the state, has led to an increasingly complex, competitive system that negatively affects the ability to conduct DRR.
\end{abstract}

\section{Keywords}

disaster risk reduction; Indonesia; governance; Myanmar; Sendai Framework

\section{Issue}

This article is part of the 'Multidisciplinary Studies' issue in Politics and Governance.

(C) 2018 by the authors; licensee Cogitatio (Lisbon, Portugal). This article is licensed under a Creative Commons Attribution 4.0 International License (CC BY).

\section{Introduction}

For decades, disaster risk reduction (DRR) has been organised around an emergency style of top-down, statecentred policies and institutions. But the past three decades have seen a global development shifting disaster response from reactive to proactive, from singular to more holistic with a focus on DRR, and from a statecentred model to forms of co-governance that recognise the importance of non-state actor involvement in disaster governance and of community-based initiatives and resilience.

This emphasis on the need for inclusive cogovernance of disaster in global and national policies is partly related to the recognition that disasters are in many places growing in number and that recurring events may have disastrous impacts but are at the same time largely predictable and part of normality. 'Living with the floods' is one of the catchphrases of this new way of thinking, reflecting a change from an earlier per- 
spective that considered floods to be abnormal riskevents that were addressed by technical measures. In the 'living with the floods' era, the focus of disaster risk governance (DRG) has shifted away from top-down emergency response measures to softer measures, such as improving the ways in which vulnerable populations and their governments deal with recurrent floods and other hazardous events. This also implies a shift in governance away from top-down disaster management and towards co-governed forms of response that involve different segments and levels of the state, as well as societal actors.

The international community has converged on the principle of 'inclusive DRR', which denotes 'the collaboration of a wide array of stakeholders operating across different scales' (Gaillard \& Mercer, 2012, p. 95). In policies and meetings, the global DRR community has consistently repeated the expected advantages of inclusive DRR governance, stressing that it will lead to more inclusive and effective disaster governance (Djalante, 2012). To achieve inclusive DRR, it is necessary to strengthen and alter the ways in which countries and institutions govern disaster. It is now widely believed that effective DRG requires the strong engagement of multiple actors involved in DRR in a country.

The United Nations International Strategy for Disaster Risk Reduction (UNISDR) has claimed that 'good governance' of disasters should be shared by multiple state and non-state actors in a country to 'elevate disaster risk reduction into a policy priority, allocate the necessary resources to it, ensure and enforce its implementation and assign accountability for failures, as well as facilitate participation by all relevant stakeholders' (UNISDR, 2004).

Governance networks are widely expected to contribute to more effective DRG (UNISDR, 2013; Warner, Waalewijn, \& Hilhorst, 2002, p. 2). Moreover, the report of the Hyogo Framework for Action claimed that multistakeholder platforms would contribute significantly to 'integrating DRR into sustainable development policies and supporting less developed countries in implementing the HFA [Hyogo Framework for Action]' (Djalante, 2012, p. 2924). It is also believed throughout the global disaster community that this and other governance networks could stimulate learning and innovation (Djalante, 2012, p. 2932).

DRR platforms have now become common in most disaster-prone countries. Since 1987, United Nations (UN) member states have been invited to establish 'national committees'-co-governance platforms that should consist of multiple actors involved in DRR, including representatives of governments, international organisations, nongovernmental organisations (NGOs) and the scientific community. UNISDR has actively encouraged the establishment of national governance networks' to provide and mobilise knowledge, skills and resources required for mainstreaming DRR into development policies, planning and programmes' (UNISDR, 2007). Data from UNISDR indicate that around 93 national platforms on DRR had developed worldwide as of 2016 (UNISDR, 2017). Both Myanmar and Indonesia have established such a platform.

Several scholars have studied disaster management networks in Asia. For instance, Djalante (2012) studied adaptive governance and multi-stakeholder platforms in Indonesia using a multi-stakeholder approach; Raju and Niekerk (2013) discussed multi-organisational coordination for disaster recovery in India; and Chui, Feng and Jordan (2014) used the same lens to explore advocacy coalition frameworks in the context of policy change in Taiwan. These authors have all related the principle of governance network to a disaster-related context in Asia. Djalante (2012, p. 2923) advocated the concept of adaptive governance as an 'alternative' in governing disaster management and placed multi-stakeholder platforms at the heart of this approach, arguing that multistakeholder platforms offer a way to manage problems with flexible and adjustable governance systems. Raju referred to 'coordination structures' to describe the network arena of disaster recovery. He argued that effective DRR politics requires clarity on rules, a willingness to coordinate, strong leadership and deliberative command. Finally, Chui et al. (2014) addressed advocacy within the groundwork of 'advocacy coalition framework[s]'. In their study, they argued that the success of advocacy through coalitions and alliances is mainly determined by stakeholders' social engagement and common commitment to work on collective action.

Despite the recognised importance of co-governance of disaster, no academic research has specifically studied the internal dynamics among actors in DRR governance networks. Therefore, this article examines the discourses and practices of different governance networks that were established to reduce disaster risk in Indonesia and Myanmar. Our article is based on extensive ethnographic fieldwork conducted in two country case studies and among a global-level DRG-governance network.

Our research aimed to understand to what extent DRR in Indonesia and Myanmar is indeed inclusive and co-governed by multiple state and non-state actors. Although it has often been suggested in the literature and in policy reports that inclusive DRR and effective DRG face challenges (Djalante, 2012, p. 2925; Raju \& Niekerk, 2013 , p. 92), not much is known about the daily practices, problems and experiences of state and non-state actors involved in DRR. Looking beyond the policy commitments on expected inclusiveness and other positive outcomes, this article investigates the realities of the actual practice of inclusive DRR in DRG in Indonesia and Myanmar and asks how the principle of inclusiveness works in practice. Has it lived up to its promise to achieve common objectives and resolve conflicts? To what extent are states willing to negotiate the power arrangements in their partnerships with non-state actors? 


\section{Conceptual Frameworks}

\subsection{Disaster Risk Reduction and Disaster Risk Governance}

In the academic and policy literature, DRR is defined as a means of 'preventing new and reducing existing disaster risk to strengthen resilience' (UNISDR, 2007). Beyond this definition, DRR has been understood as a 'conceptual framework to minimise vulnerabilities and disaster risks, to avoid (prevention) and to limit (mitigation and preparedness) the adverse impacts of hazards' (UNISDR, 2008). In the context of DRR, the concept of DRG has been used as a frame to explain structural arrangements and multifaceted interactions among actors working with the objective of reducing risk.

The phrase 'disaster risk governance' has been used extensively in policy practice. UNISDR refers to DRG as 'the system of institutions, mechanisms, policy and legal frameworks and other arrangements to guide, coordinate and oversee disaster risk reduction and related areas of policy' (UNISDR, 2007). In the DRR global policy setting, the Guiding Principles of the Sendai Framework for Action 2015-2030 explicitly states that 'disaster risk reduction requires an all-of-society engagement and partnership'. It requires empowerment and inclusive, accessible and non-discriminatory participation, paying special attention to people disproportionately affected by disasters, especially those belonging to the poorest groups in society. Inclusiveness in DRR is strongly related to the involvement of all actors in collective action on DRR.

DRG, in contrast to disaster governance, aims to approach the complex dynamics of institutional settings, power relations and policy advocacy in the specific context of reducing risk. DRG concerns the entire structure of the phases of disaster management (preparedness, response, recovery and rehabilitation). However, many authors use the phrases 'disaster risk governance' and 'disaster governance' interchangeably, and a substantial number of well-written journal articles using the phrase 'disaster governance' may be seen to speak about DRG (Ahrens \& Rudolph, 2006; Cho, 2014; Enia, 2013; Gerber, 2007; Lassa, 2010; Lindsay, 2014; Moe, 2010; Niekerk, 2015; Seng, 2010; Tierney, 2012).

\subsection{Disaster Risk Governance}

'Governance' is different from 'government'. Whereas government is associated with the 'authoritative expression of the state' that is 'usually thought to dictate to and control other state bodies' (Heywood, 2004, p. 77), governance denotes 'interorganizational networks' that 'complement markets and hierarchies as governing structures' (Rhodes, 1996, p. 652). More specifically, the concept of governance is defined as 'a complex set of values, norms, processes and institutions used by a society to manage its development and resolve conflict' (Kohler-
Koch, 2005). Governance is a way of steering and governing by engaging non-state actors in the policy process (Ewalt, 2001; Peters \& Pierre, 1998; Rhodes, 1996; Stoker, 1998; van Leeuwen \& van Tatenhove, 2010). Governance aims to challenge the traditional policy process, where the state stands as the core entity. Governance networks are considered to be 'self-organising' when actors develop and regulate their interactions using rules of the game that are 'negotiated and agreed' by the participants, rather than following the dictates of the state (Rhodes, 1996). Governance scholars frequently use terms such as 'coordination, cooperation, partnership, joint-working, alliance, collaboration, and network' (Mardiah, Lovett, \& Evanty, 2017, p. 58). Governance networks emphasise the work of multiple actors who act autonomously but relate interdependently within the institutionalised framework of the policy-making process (Torfing, Peters, Pierre, \& Sørensen, 2012).

\section{Methods and Case Selection}

This article is based on an ethnographic study conducted by the first author. The co-authors guided the study and participated in the analysis and writing. At the global level, the first author participated in the World Conference on DRR, in Sendai, 2015, and the Asian Ministerial Conference on DRR, in Bangkok, 2014. At the latter conference, the first author attended a high-level ministerial meeting as an observer. The research was primarily conducted through long-term fieldwork and participatory observation in DRG-governance networks in Myanmar and Indonesia.

Indonesia and Myanmar were selected as cases for the study because they offer relevant, contrasting political contexts: Indonesia has a longer history with democratic governance institutions, as well as a largely national-led response to disasters. Myanmar, in contrast, has only started to develop DRG over the past 10 years, and policies are still largely led by international actors.

Both countries are also extremely vulnerable to disasters, making disaster response a particularly relevant topic of study. Asia has the highest number of disaster events in the world. Data from the Asian Disaster Reduction Centre show that $44.4 \%$ of the world's disaster events have occurred in Asia. The hazardous profile corresponds to $82 \%$ of the people killed, $94 \%$ of those affected and $88.7 \%$ of the total economic damage from disaster events worldwide being in Asia (Asian Disaster Reduction Center, 2011). Within Southeast Asia, Indonesia and Myanmar have the highest levels of vulnerability, based on the indicator of the average annual number of casualties per one million residents (UNISDR, 2010). The enormous number of people killed in the 2004 tsunami mega-disaster and in cyclone Nargis in 2008 showed both countries' high level of susceptibility to disasters.

The research design involved the use of multiple qualitative methods of data collection for each of the case studies: (1) desk study to review and analyse policy docu- 
ments and the basic conceptual framework of the politics of DRG, global frameworks on DRR, global norms, political changes and decentralisation; (2) semi-structured interviews with government officials and non-state actors from both international organisations and NGOs; (3) focus group discussions in which various community groups at the village level were interviewed to study community perspectives towards risk, the DRR project, NGOs and the roles of the government; (4) a qualitative impact study to observe the implementation of a DRR project at the community level by an alliance of NGOs; and (5) participant observation in focus group discussions, reviewing minutes of meetings and observations from national and international conferences/workshops, and participation in an internship programme at a UN agency in Myanmar.

The field research was conducted over a time span of 18 months. A total of 129 people in Indonesia and 78 in Myanmar participated in this research through semi-structured interviews or focus group discussions. These participants included both government officials and non-state actors (working for international disastergovernance organisations or NGOs). The researchers used purposive sampling to select the interviewees by identifying and selecting participants based on their involvement in DRG.

The interviews addressed four topics: the role of actors, the agenda, interaction with other stakeholders and the articulation of interests (power relations). In Indonesia, the interviews were conducted in the local language, Bahasa Indonesia. In Myanmar, both English and Burmese were used, with the aid of an interpreter.

\section{Research Findings}

\subsection{Political Changes in Indonesia and Myanmar Influence the Strengthening of Inclusive Disaster Risk Governance}

\subsubsection{Decentralised Disaster Risk Governance in Indonesia}

Indonesia offers a strong example of how political changes influence DRG, on both the national and the local level. In 1998, Indonesian political reforms comprehensively introduced decentralisation. This decentralisation has inspired the architecture of DRG in Indonesia, where provincial and regency ${ }^{1}$ governments have been made entirely responsible for the implementation of the DRR policy agenda. The Disaster Management Law No 24, 2007 mandates the central and regency governments to share responsibility and authority for disaster management. At the national level, referring to the Law No 24, 2007, Article 12, the Indonesian National Agency for Disaster Management (Badan Nasional Penanggulangan Bencana [BNPB]) was established to provide guidance, direction, standards and requirements for disaster management (Law No 24, 2007, Article 12).
From 2010 to 2013, Indonesian Regional Agencies for Disaster Management (Badan Penanggulangan Bencana Daerah [BPBD]) were introduced. BPBDs were established in almost $90 \%$ of the provinces and regions in Indonesia (BNPB, 2014). In addition, the growth of democratisation beginning in 1998 has led to the increasing influence of non-state actors and community initiatives. Freedom of speech is one of the pillars of political reform in Indonesia, and it appears that many nonstate actors want to have a voice in DRR politics. Indonesian civil society actively engages in DRR through several multi-stakeholder platforms that are independent of the government: the National Platform (Platform Nasional [PLANAS]), Indonesian Civil Society for Disaster Management (Masyarakat Peduli Bencana Indonesia), Indonesian Expertise on Disaster Management (Ikatan Ahli Bencana Indonesia), the University Forum (Forum Universitas), the Region DRR Forum (Forum Peduli Bencana Daerah) and the Village DRR Forum (Forum Peduli Bencana Desa).

However, in practice, we found that the co-governance of disaster appeared complex and frustrating for many of the actors involved. Even when interviewees theoretically supported the idea of co-governance, indicating that it would make disaster management more effective through empowering local actors, they also highlighted many practical problems with its implementation.

The head of BNPB, the Indonesian National Agency for Disaster Management, considered the independence of local government to be one of the indicators of national resilience. 'Local government acts as the frontline in formulating local policy', he said in an interview, 'arranging resources and building community capacity'. This idea was articulated in a similar way by multiple staff members working at the national level. It echoes the idea of 'empowering' local government to govern disaster management without depending on the hierarchy of a top-down control mechanism. A mid-level Ministry of Home Affairs officer emphasised that, as long as the provincial and regency levels can perform disaster management, the main responsibility of the central government is mostly to provide guidance, assistance and capacity building:

Like children who first learn to walk, if they [the provincial/regency governments] fall, let it be; it's part of the learning process. However, if they walk and stagger unsteadily, we [the central government] will be there to help them. (interview with a male Ministry of Home Affairs officer, 1 November 2015)

In contrast, at the local level, BPBD staff members spoke of 'decentralised disaster risk governance' in a negative tone. They mentioned the lack of budget, human resources and capacity as factors hampering their work in the region. For example, one of the BPBD heads claimed that 'It's better to work in a vertical structure with BNPB

\footnotetext{
${ }^{1}$ The term 'regency' in the Indonesian context refers to a sub-national level of government.
} 
because the budget from the regency level is limited' (interview with a male BPBD head in Nusa Tenggara Timor, 28 July 2014).

The same informant also explained that staff capacity had degraded because of decentralisation:

In bureaucracy, you will not get promoted if you're not moving to a different office [function]; at minimum, you would be rotated to two different functions. Thus, on the previous DRR Day held in Bengkulu, weall the heads of BPBD - wanted to have centralisation with BNPB. [Centralisation] would make the rotation of human resources rest on the responsibility of BNPB, and it would no longer be part of the authority of the Head of Regency. Here, we have often received new staff from different functions that have nothing to do with disaster management-for instance, the rotation of staff from the Department of Agriculture-so every year we received new staff who understand nothing. (interview with a male head of BPBD in Nusa Tenggara Timur, 28 July 2014)

Similar complaints were made by several of this informant's colleagues. These complaints were often related to the regency office's financial situation. At the meeting of the Indonesian delegation for the World Conference on DRR, a high-ranking BNPB officer noted that, for the five-year period from 2015 to 2019, the central agency of BNPB received IDR 8.7 trillion (equal to EUR 580 million). This is extremely high compared with the budget of BPBD at the regency level in NTT (IDR 6.5 billion, equal to EUR 433,000). Although BNPB is allocated approximately IDR 1.2 billion-2.4 billion yearly for each province, some BPBD personnel said that they never received the funding. A head of BPBD explained what happens in reality:

We received financial assistance from BNPB during a disaster response in the aftermath of a volcanic eruption; aside from that, we don't receive anything. (Interview with a male BPBD head in NTT, 28 July 2014)

Furthermore, it became clear from the interviews that $B P B D$ had insufficient funds to deliver services on DRRspecific agendas. Our analysis of the BPBD budget document showed that budget allocations for DRR are equal to the operations budget (e.g., staff expenses, business trips, accommodations, transportation, consultancy and meals); hence, there are no funds set aside for activities at community level or investments in DRR. Poor capacity also leads to weak budget absorption at the local level. The national system obliges government bodies to return unspent funds to the Ministry of Finance at the end of fiscal year, and, because of the obstacles described here, the funds were often received too late, at the end of the fiscal year:

Most of the budget was returned to Jakarta [at the end of the fiscal year] because some BPBD [agencies] did not know how to use it and the budget came too late. (Interview with a male BNPB staff member, 17 November 2014)

In addition to a lack of financial resources, there were also problems concerning human resources. Decentralisation has shifted political gravity to the subnational level. In practice, this leads to a situation where the promotion and rotation of government officials happens within and between local administrative bodies, which hampers specialisation.

During an interview, a head of BPBD noted that BPBD is perceived as a new player in the bureaucracy arena at the regency level, and as 'hardly powerful, unpopular and an outcast'. He also explained that BPBD suffers from high rotation among its officials, who have insufficient backgrounds and competencies because the agency depends on staff allocated to them by the mayor and the governor, who have no special interest in DRR:

Every time we trained BPBD staff, the government officers who came to Jakarta were new staff members. Decentralisation has [led to] a high and dynamic rotation for government officers. I spoke in front of the mayor at a meeting and asked whether the head of BPBD could be exempted from bureaucratic rotation. But they [the mayor] said, 'it's a decentralisation era; we [the mayors] are the ones who know who have the potential to lead [BPBD]'. (Interview with a male BNPB staff member, 17 November 2014)

Another informant said that 'Bureaucratic rotation in BPBD is also our problem, but we can't push more because it's a decentralisation era' (interview on 1 November 2015). The high rotation of officials hinders the sustainability of BPBD's programme and is detrimental to the process of knowledge transfer within the organisation.

In conclusion, although actors at both the national and the local level support the idea of co-governance in theory, they face challenges in daily practice. In particular, BPBD suffers from insufficient human resource capacity caused by a premature decentralisation process and strong local politics, resulting in government officials not being adequately qualified based on merit.

\subsubsection{Disaster Risk Governance in Transitional Myanmar}

In 2008, cyclone Nargis created momentum for Myanmar to open up to the international community. The cyclone was the worst disaster in Myanmar's history, claiming the lives of an estimated 138,000 people. Nargis turned out to be a game changer in the policy arena of DRR. In the national arena, the government of Myanmar has been working closely with the Disaster Risk Reduction Working Group (DRR WG), which aims to assist the government in achieving a 'resilient country' environment. Since its establishment after Nargis in 2008, the 
DRR WG has transformed into a multi-stakeholder network. Its members include auxiliary government bodies (e.g., Myanmar Red Cross); international organisations (United Nations Development Programme and others); international and national NGOs; donor agencies (e.g., Japan International Cooperation Agency, Caritas Switzerland); professional societies (e.g., Myanmar Engineering Society) and academic organisations (e.g., Yangon Technological University, University of Yangon). The DRR WG is the platform to discuss, formulate and implement the DRR agenda. Although the government is one of the actors in this network, this working group is positioned outside the government structure on disaster management. The DRR WG has been involved in policy consultations, providing technical support to the government on policy development and report preparation, including developing a draft note for Myanmar's 2015 'Action Plan for DRR'.

In a transitional setting such as Myanmar, the change process is mostly felt in urban areas like Yangon. The following interview extracts show that, at the local level (district, township, village-tract), the status quo has predominantly been maintained, and international actors in particular described a lack of translation of policy to lower levels of governance:

The top level of the government changes, but the middle level and the lower level is not [changing] as fast as the top level. (interview with a female UN agency programme coordinator, 17 October 2014)

The middle-low bureaucratic staff have poor knowledge/capacity on disaster management and do not always understand the reality on the ground. (Interview with a female UN agency staff member, 17 October 2014)

But problems were not felt only at local levels. From the interviews with national-level actors involved in disaster management, it became clear that the new practice of the governance network has exposed the national government to a new way of governing. This is challenging. It is a daily experience for government decision-makers in Myanmar to receive requests to establish cooperation and partnership from International Organizations, NGOs and the private sector. Consequently, the ongoing transition pushes the government to reform almost all aspects of policy. The government is occupied with this reform process, including new partnership arrangements from various initiatives. This situation often leads to long delays in the decision-making process.

Government departments in this transition periodthey are very, very busy. And then, they are not that clear what is the direction, so there were many confusions. In the past, they needed to listen to only the supervisor, only the head of department. Now they have to listen to [the] media while they also have to listen to civil society also; then sometimes [they] take decisions very slowly. (interview with a female UN agency staff member, 17 October 2014)

[Working with the government] is like [a] double[edged] sword; now they are open, but everybody now works with them. [There is a] lack of capacity to coordinate [and] the demand is really high, [but] the staffing, training people is the same quantity. They don't have a lot of capacity. They have to build the capacity. Because it's evolving with [a] different structure-working groups, different ministries. There are so many groups-how do they talk to each other and link to each other? It has been a challenge for the government and also for us. (Interview with a male international NGO programme coordinator, 4 October 2014)

These interview extracts show how the government's exposure to the new practice of inclusiveness has also had an impact on other actors in the governance network. The delay of responses to the initiatives from non-state actors is only one of the effects. There are also implicit problems that endanger the commitment to the governance network. In the heavily bureaucratic government setting of Myanmar, some NGOs admitted that it is difficult to get access to the highest levels of government.

\subsection{Heavy Organisational Set-Up of Disaster Risk Governance}

In both countries examined here, a striking feature of DRG is its heavy organisational set-up. The implementation of 'decentralised DRR' in Indonesia remains problematic because of the complexity of power sharing between the central and local governments and because of bureaucratic heaviness. In the present organisational structure, BNPB and BPBD are connected by a 'coordination line' rather than a 'command line'. The head of BNPB applauded the independence of local government as one of the indicators of national resilience. Local government acts as the frontline in formulating local policy, he said, arranging resources and building community capacity. However, staff members of the regency body of BPBD mentioned the aforementioned lack of budget, human resources and capacity as factors hampering their work in the region.

In addition, intra-government coordination remains a major issue for DRG in Indonesia, where approximately 22 ministries and government agencies work on DRRrelated issues. Inter-ministerial meetings were mostly conducted ad hoc around programmes or events, with no specific mechanism for regular coordination; for example, in 2014, several ministries tried to work together to integrate disaster management under the Rancangan Pembangunan Jangka Menengah Nasional, with Badan Perencanaan Pembangunan Nasional coordinating. 
As the following comment by a research participant suggests, such coordination of the bureaucracy-heavy organisation at the national level appeared to be a real challenge for DRG in Indonesia:

Coordination is easy to say but difficult to implement. Each ministry has their own DRR movement, which sometimes is not synergised and integrated. We aim to control the planning, which before was the domain of BAPPENAS and the Ministry of Finance. Now, all programmes are brought to us before passing it to BAPPENAS. (interview with a male Coordinating Ministry of Human Development and Culture staff member, 4 November 2015)

In Myanmar, information exchange processes became a real challenge for inter-ministerial coordination. The coordination mechanisms among the ministries failed to fill the information gap with other related ministries. The Ministry of Social Welfare Relief and Resettlement, through the Relief and Resettlement Department, is a key government body tasked with disaster management. Other relevant ministries working intensely on DRR-related issues include the Ministry of Environment and Conservation of Forestry, the Ministry of Health, the Ministry of Education, the Ministry of Construction, and Myanmar Safer Settlement and Urban Research. In a dam construction project, the Relief and Resettlement Department asserted that they had not been fully informed about the construction process, although it was crucial for them to ensure the construction was not taking place in 'disaster-prone areas': 'We lacked complete information on what and how they do it [the project]'.

Many informants expressed the view that, while the transfiguration to open and engaging practice is ongoing, the old bureaucratic culture, which mostly promoted a closed and command-driven hierarchy, continues to exist. The highly bureaucratic command structure that characterises Myanmar's historical and political context has also shaped the political culture of current government officials, who have lived under decades of authoritarian leadership:

They [the government] were in the command system for many years, they were trained to listen [to the higher command]. It's really difficult to change the mind-set of the government department personnel...to have that interactive discussion, to have consultation, to find the consensus....In the past, they didn't talk to people and people didn't talk to government departments. People never think that if we interact with government departments they will respond....It's not easy to talk together, to find the way together. If we think that it will work, it is just a story. It would not work in this short period. We need some time to bridge through that situation. (interview with a female UN agency staff member, 17 October 2014)
This statement illustrates a tendency that was also mentioned in many other interviews: the heavy bureaucratic structure continuously demanding a hierarchical and topdown decision-making process. Within this procedural structure, there are many potential pitfalls for achieving effective decision-making processes. Although there have been some changes introduced, the old practice of directing decision-making processes to higher authorities remains tangibly real.

\subsection{Government Dominance in Disaster Risk Governance}

Another major issue found in the two countries concerned the dominance of the government. In Indonesia, the institutionalisation of DRR followed a co-governance approach through the work of PLANAS, the National Platform. This platform is a multi-stakeholder forum for DRR in Indonesia in which the government is one of the members. During interviews and focus group discussions, both government and non-state actors acknowledged the important role of each party and affirmed the 'good partnership'. But, although on paper (and in formal interviews with outsiders such as the first author) civil society-government advocacy channels appear to be relatively open, we found that, in practice, the relations between government and non-state actors remained highly asymmetrical. Representatives of PLANAS revealed that parties work together to 'a limited level'. The government engages PLANAS only at the final stage of policy evaluations. In interviews, members of the network expressed demands for a more comprehensive engagement. For example, PLANAS was not fully involved in the formulation of DRR national planning and action through the RPJMN or the National Action Plan on DRR (Rencana Aksi Nasional), which serve as the primary references for Indonesia's national programme on DRR. In other words, the government determines and controls the policy process.

In Myanmar, interview with the DRR WG claimed to be the 'government-led model of DRR Coordination' This explicitly placed the government in a central position in the network, which was reflected in the DRR WG strategic framework, where three of six outcomes for the DRR WG were directed at meeting government needs (i.e., inclusive policy and a legal framework on DRR [outcome 1]; increased government capacity at all levels [outcome 2]; and the government being provided with tools, experiences and capacities [outcome 3]). Additionally, the network has very clearly been heading further in the direction of a 'government-led' platform. Although there was room for negotiation with the government, the power relations between state and non-state actors were built on an asymmetrical foundation with mutual benefits. The government works closely with the DRR WG to achieve the government's agenda-setting goals, and the relationship between the government and the DRR WG members is crucial for achieving the group's organisational 
mandates. However, the partnership initiative was undertaken predominantly to fill the government's needs (demand-driven).

\section{Conclusions}

This article has presented findings about the inner workings of the co-governance of DRG in Indonesia and Myanmar. In both countries, we found that the global trend towards a shift from a top-down disaster response to cogoverned, inclusive forms of DRG is visible in the policies and organisation of governance. There were differences between the two countries, especially in relation to the role of the international community (strong in Myanmar) and the role of civil society (better recognised in Indonesia). However, in both countries, we found that, on closer scrutiny, it remains to be seen to what extent the ideal of co-governance will move beyond rhetoric, as both countries exhibit a tendency for the state to retain central power and marginalise non-state actors. The advocacy arena for NGOs and other non-state actors has been widening, but this space is also shrinking, because the decision-making process has failed to develop into a real partnership and the government remains dominant in policy processes.

However, we also found that, in both Indonesia and Myanmar, advocacy through alliances and consortiums is continuously developing: Improvements in capacity, resources and strategy to build a robust advocacy profile significantly strengthen credibility and bargaining position vis-à-vis the government. Although we found that shared commitment-considered crucial by Chui et al. (2014)-is important, we emphasise that the influence of stakeholders is determined by both the network and the positional power of the network vis-à-vis the government, and the process of interactive governance requires actors on both sides (government and non-state actors) to play an active role.

The co-governance model of DRG, despite its global popularity, may not rest on a shared commitment. In particular in Indonesia, we found that actors at decentralised local levels would have preferred a clearer hierarchical system that would give them more leeway to develop specialised DRR and a clear negotiation situation to obtain more funds from the central level.

Our research also found that co-governance has led to substantive implementation challenges. Far from clear with respect to the rules and command structures that Raju and Niekerk (2013) saw as key to DRG, we found that the organisational structures in both countries are heavy on bureaucracy and suffer from poorly integrated work, coordination issues, and organisational ego and competition. Importantly, in both countries, we found that the set-up of co-governance has not led to the strengthening of inclusive DRR at local levels. In Indonesia, decentralised budgets leave no room for DRR programmes at local level, and, in Myanmar, co-governance has not yet been translated to the local level. Even though we find that co-governance has led to more inclusion in policy processes in both countries, the prospect of more effective and innovative DRR at the local level (Djalante, 2012) remains elusive.

\section{Acknowledgements}

This study was undertaken as part of a PhD trajectory in Humanitarian Aid and Reconstruction at the International Institute of International Studies (ISS), the Netherlands. We are grateful to the Netherlands Universities Foundation for International Cooperation (NUFFIC) to grant this project under the NUFFIC Fellowship Programme (NFP). The article was also made possible by a $\mathrm{VICl}$ grant of the Netherlands Organisation for Scientific Research NWO, grant number 453-14-013.

\section{Conflict of Interests}

The authors declare no conflict of interests.

\section{References}

Asian Disaster Reduction Center. (2011). Natural disaster data book: An analytical overview. Asian Disaster Reduction Center. Retrieved from http://www. adrc.asia/publications/databook/ORG/databook_ 2011/pdf/DataBook2011_e.pdf

Ahrens, J., \& Rudolph, P. (2006). The importance of risk governance. Journal of Contingencies and Crises Management, 14(4), 207-220.

Badan Nasional Penanggulangan Bencana. (2014). Indonesian national progress report on the Hyogo Framework for Action.

Cho, A. (2014). Post-tsunami recovery and reconstruction: Governance issues and implications of the Great East Japan Earthquake. Journal of Disasters, 38(2), 157-178.

Chui, C., Feng, J., \& Jordan, L. (2014). From good practice to policy formation: The impact of third sector on disaster management in Taiwan. International Journal of Disaster Risk Reduction, 10(2014), 28-37.

Djalante, R. (2012). Adaptive governance and resilience: The role of multi-stakeholder platforms in Indonesia. Natural Hazards and Earth System Sciences, 12(9), 2923-2942. https://doi.org/10.5194/nhess-12-29232012

Enia, J. (2013). The spotty record of the Hyogo Framework for Action: Understanding the incentives of natural disaster politics and policy making. The Social Science Journal, 50(2), 213-224. https://doi.org/ 10.1016/j.soscij.2012.12.004

Ewalt, J. G. (2001). Theories of governance and new public management: Links to understanding welfare policy implementation. Paper presented at the Annual Conference of the American Society for Public Administration. Newark, NJ.

Gaillard, J. C., \& Mercer, J. (2012). From knowledge 
to action: Bridging gaps in disaster risk reduction. Progress in Human Geography, 37(1) 93-114. https://doi.org/10.1177/0309132512446717

Gerber, B. (2007). Disaster management in the United States: Examining key political changes and policy challenges. The Policy Studies Journal, 35(2), 227-238.

Heywood, A. (2004). Political theory: An introduction. London: Palgrave Macmillan.

Kohler-Koch, B. (2005). European governance \& system integration (European Governance Papers No. N-0502). Vienna: European Governance Papers.

Lassa, J. (2010). Institutional vulnerability and governance of disaster risk reduction: Macro, meso, micro scale assessment (Unpublished Doctoral Dissertation). University of Bonn, Bonn, Germany.

Lindsay, J. (2014). Multilevel governance and emergency management in Canadian municipalities. Journal of Disaster Prevention and Management, 23(3), 309-310. https://doi.org/10.1108/DPM-012014-0017

Mardiah, A., Lovett, J., \& Evanty, N. (2017). Toward integrated and inclusive disaster risk reduction in Indonesia: Review of regulatory frameworks and institutional networks. In R. Djalante, M. Garschagen, F. Thomalla, \& R. Shaw (Eds.), Disaster risk reduction in Indonesia: Progress, challenges, and issues (pp. 57-84). Cham: Springer.

Moe, T. L. (2010). Cleanup after Katrina: An analysis on policy, process, priorities, problems, and politics. Disaster Prevention and Management, 19(3), 314-332. https://doi.org/10.1108/09653561011052493

Niekerk, D. (2015). Disaster risk governance in Africa: A retrospective assessment of progress in against the Hyogo Framework for Action (2000-2012). Journal of Disaster Prevention and Management, 24(3), 397-416.

Peters, B. G., \& Pierre, J. (1998). Governance without government? Rethinking public administration. Journal of Public Administration Research and Theory, 8(2), 223-243.

Raju, E., \& Niekerk, D. (2013). Intra-governmental coordination for sustainable disaster recovery: A case study of the Eden District municipality, South Africa. International Journal of Disaster Risk Reduction, 4, 92-99.

Rhodes, R. (1996). The new governance: Governing without government. Political Studies, XLIV, 652-667.

Seng, D. C. (2010). The role of governance, multi institutional arrangements and polycentric frameworks for a resilient tsunami early warning system in Indonesia (Unpublished Doctoral Dissertation). University of Bonn, Bonn, Germany.

Stoker, G. (1998). Governance as a theory: Five propo- sitions. International Social Science Journal, 50(155), 17-28.

Tierney, K. (2012). Disaster governance: Social, political and economic dimensions. Annual Review of Environment and Resources, 37, 341-363.

Torfing, J., Peters, G., Pierre, J., \& Sørensen, E. (2012). Interactive governance: Advancing the paradigm. Oxford: Oxford University Press.

United Nations International Strategy for Disaster Risk Reduction. (2004). Disaster risk reduction, governance and development. Geneva: United Nations International Strategy for Disaster Risk Reduction. Retrieved from https://www.unisdr.org/we/ inform/publications/8546

United Nations International Strategy for Disaster Risk Reduction. (2007). Terminology. United Nations International Strategy for Disaster Reduction. Retrieved from https://www.unisdr.org/we/ inform/terminology\#letter-d

United Nations International Strategy for Disaster Reduction. (2008). Disaster Risk Management System Analysis: A Guide Book. Retrieved from http:// www.unisdr.org/files/3769_ai504e00.pdf

United Nations International Strategy for Disaster Risk Reduction. (2010). Synthesis report on ten ASEAN countries disaster risk assessment. Geneva: United Nations International Strategy for Disaster Risk Reduction. Retrieved from: http://www.unisdr.org/ files/18872_asean.pdf

United Nations International Strategy for Disaster Risk Reduction. (2013). Findings of the review of national platforms for DRR 2012-2013. Geneva: United Nations International Strategy for Disaster Risk Reduction. Retrieved from https://www.unisdr. org/we/inform/publications/35266

United Nations International Strategy for Disaster Risk Reduction. (2017). Words into action: National focal points for Disaster Risk Reduction, platforms for Disaster Risk Reduction, local platforms for Disaster Risk Reduction. Geneva: United Nations International Strategy for Disaster Risk Reduction. Retrieved from https://www.unisdr.org/we/inform/publications/53 055

van Leeuwen, J., \& van Tatenhove, J. (2010). The triangle of marine governance in the environmental governance of Dutch offshore platforms. Marine Policy, 34(3), 590-597. https://doi.org/10.1016/ j.marpol.2009.11.006

Warner, J., Waalewijn, P., \& Hilhorst, D. (2002). Public participation in disaster-prone watersheds: Time for multi-stakeholder platforms? Paper for the Water and Climate Dialogue, Wageningen University, Wageningen, the Netherlands. 


\section{About the Authors}
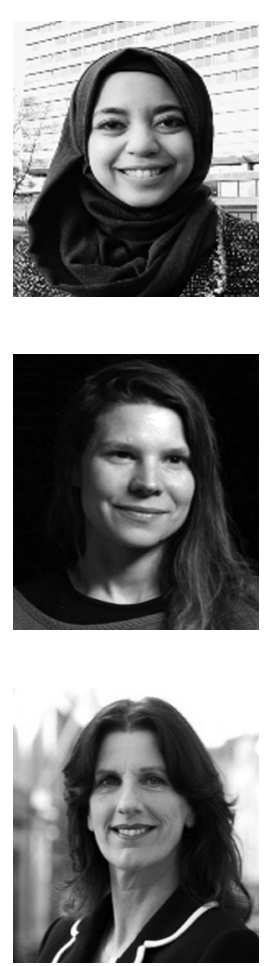

Annisa Gita Srikandini is a Lecturer in the Department of International Relations, Universitas Gadjah Mada, Indonesia. Her research and engagement are on the area of humanitarian action and disaster risk governance, particularly in Indonesia and Myanmar. Annisa is the author of the book Responsibility to Protect in Myanmar after Cyclone Nargis (2011). Further, she wrote numbers of academic articles on humanitarian diplomacy, humanitarian space in ASEAN, Disaster Risk Reduction (DRR) in Indonesia. In 2018, she completed her PhD from the International Institute of Social Studies (ISS), the Netherlands, with the dissertation 'Politics of Disaster Risk Governance in Indonesia and Myanmar'.

Roanne van Voorst is a Post-Doctoral Researcher involved in the research project "When disaster meets conflict. Disaster response of humanitarian aid and local state and non-state institutions in different conflict scenarios", the International Institute of Social Studies (ISS), the Netherlands. She has a background in anthropology and development; her main research interests focus on natural hazard, poverty and humanitarian aid. She has also done research on the social effects of climate changes in Greenland. Furthermore, she has worked as a consultant for the Danish Institute of International Studies (DIIS) on a research project on urbanization, governance and international development.

Dorothea Hilhorst is Professor of Humanitarian Aid and Reconstruction at the International Institute of Social Studies (ISS) of Erasmus University Rotterdam. Her research concerns aid-society relations in humanitarian crises and recovery. She has published widely in her domain. Her books include People, Aid and Institutions in Socio-Economic Recovery. Facing Fragilities (with B. Weijs and G. van der Haar, London, Earthscan/Routledge); and The Real World of NGOs: Discourse, Diversity and Development (London, Zedbooks, 2003). 